\title{
A Review of National and International Online Medical Systems
}

\author{
Carmen Catalina RUSU1,2, Viorica BADEA ${ }^{3}$, Luigi Renato MISTODIE ${ }^{1,2}$, Costica VOICU²
}

\begin{abstract}
Health and the access to medical services are key factors in the functioning of a sustainable society. In order to provide access to medical and health services, in the conditions of digitalization and implementation of ITC technologies, it is necessary to innovate and achieve synergies between digital and medical technologies. Digitization, innovation and research should be complementary fields that represent the engines of a modern digital economy. In this context, the main objective of this paper is to perform an analysis on the online medical systems, both nationally and internationally. This analysis aims to identify the technologies and tools for information and prevention, existing ICT products in the medical field and online medical platforms from Romania and abroad. The main aspects identified in the analysis will represent the premises for designing an innovative online platform, which will aim to increase the visibility of scientific information, facilitate access to medical materials and provide personalized digital medical services, created by members of the innovative cluster network "For Health Dunarea de Jos", existing in the South-East region of Romania.
\end{abstract}

Keywords: health, medical online platforms, ITC, digitalisation, innovation, health cluster.

\section{Rezumat:}

Sănătatea și accesul la serviciile medicale sunt factori esențiali ai funcționării unei societăți durabile. Pentru a asigura accesul la serviciile medicale și de sănătate, în condițiile digitalizării și implementării tehnologiilor informaționale, este necesară inovarea digitală și realizarea sinergiilor între tehnologiile digitale și medicale. Digitalizarea, inovarea și cercetarea trebuie să fie domenii complementare care să reprezinte motoarele unei economii digitale moderne. În acest context, principalul obiectiv al prezentei lucrări este realizarea unei analize a sistemelor medicale online, existente la momentul actual, atât pe plan național cât și internațional. Această analiză vizează identificarea tehnologiilor și instrumentelor privind informarea și prevenția, produselor TIC existente în domeniul medical și a platformelor medicale online din România și pe plan internațional. Principalele aspecte identificate în urma acestei analize vor constitui premizele realizării unei platforme inovative online, care va avea ca scop creșterea vizibilității informațiilor științifice, facilitarea accesului la informația de ordin medical și oferirea unor servicii medicale digitale personalizate, realizate de membrii rețelei clusterului inovativ „Pentru Sănătate Dunărea de Jos”, existent în regiunea de Sud-Est a României.

Cuvinte cheie: sănătate, platforme digitale medicale, TIC, digitalizare, inovare, cluster medical.

\footnotetext{
1 "Dunarea de Jos" University of Galati, Romania

${ }^{2}$ Innovative Cluster „For Health Dunarea de Jos", Galati, Romania

${ }^{3}$ Open Hub Creative Cluster, Galati, Romania
}

Corresponding author.

Carmen Catalina RUSU, "Dunarea de Jos" University of Galati, Galati, Romania.

E-mail: carmen.rusu@ugal.ro 


\section{INTRODUCTION}

Analysing the deployment of previous industrial revolutions: steam, electricity and information technology, it becomes indisputable that the fourth industrial revolution is when digital technology begins to integrate with the physical and biological one ${ }^{1}$.

Two defining stages can be seen on how industries are transformed. The first change is the proliferation of digital technologies that bridges the gap between the physical and virtual worlds. Open Source platforms, serviced through mobile apps, allow us to do everything quickly and conveniently. The second change influences the business model. Being stimulated by modern technology, companies have gone from company/supplier-centered communication to customer/user-centered communication. As users get used to the convenience of these new business models, even the most stable industries will have to develop their offerings. One of the industries influenced by the wave of digital technology is the medical industry whose efficiency and accessibility is invaluable at the social-economic level ${ }^{2}$.

A study by McKinsey \& Company - an internationally recognized company with the aim of global consulting management, deals with the impact of digitalization of health in public perception. There is the perception that patients are resistant to digital systems, as they intervene directly in their relationship with the doctor. There is also the suspicion of relatively low use of health services, if they involve a digital component. However, the survey shows that these reluctances are due to the fact that digital health services do not meet the population (patient) direct needs, or are presumed to be of poor quality. On the other hand, more than 75 percent of respondents want to use digital healthcare services, as long as these services meet their real needs and have a high level of professionalism. In addition, more than $75 \%$ of all patients expect to use digital healthcare services in the near future ${ }^{3}$.

Romania ranks $28^{\text {th }}$ in the European Union in the DESI-Digital Economic and Society Index, calculated by the European Commission, but has a very high potential for development in this area. The SANINFO project, managed by innovative cluster „For Health Dunarea de Jos", existing in the South-East region of Romania, aims to encourage the future of the medical system, in the digital environment, whereby to speed up the communication, information, treatments and medical responses, in case of the trauma ${ }^{4}$.

One of the factors influencing the performance of healthcare systems is technological progress and its evolution in the digitisation of health services. In the medical industry, digitalisation opens up many new opportunities: the establishment of electronic patient records, remote monitoring of patients with chronic diseases or the elderly, the implementation of e-Health services in isolated areas, providing remote diagnostic services and more. Digitalised health services can provide a better prognosis for patients and contribute to the sustainability of health systems if designed and implemented correctly.

\section{ONLINE MEDICAL PLATFORMS IN ROMANIA}

In recent years, Romania has seen a considerable increase in the number of online platforms offering healthcare to users. Most of them specialize in a particular medical niche (oncology, paediatrics, etc.) or on a particular service (rate comparison algorithm, online appointments, etc.).

Following a market study, the South-Eastern region of Romania does not benefit from the same number of online medical services as the central area. There are also few platforms that incorporate a wide range of health services without specialising in a single service. (e.g. Schedules, price comparison, online chat).

Mediprice is medical platform that allows users to compare medical rates. This medical platform was born out of the need of project developers to have faster access to the prices of medical analyses and thus, after no year of existence on the market, proved to be useful for those who chose a private medical service (Figure 1). In a Mediprice study about the most searched words on Google, one can list: „private clinics”, „private hospital”, „medical analyses”, ,where I can do MRI”, , chest pain”, „dental pain”, „back pain”. At the same time, in recent years, searches for information on medical services on a mobile device (phone, tablet) have increased by up

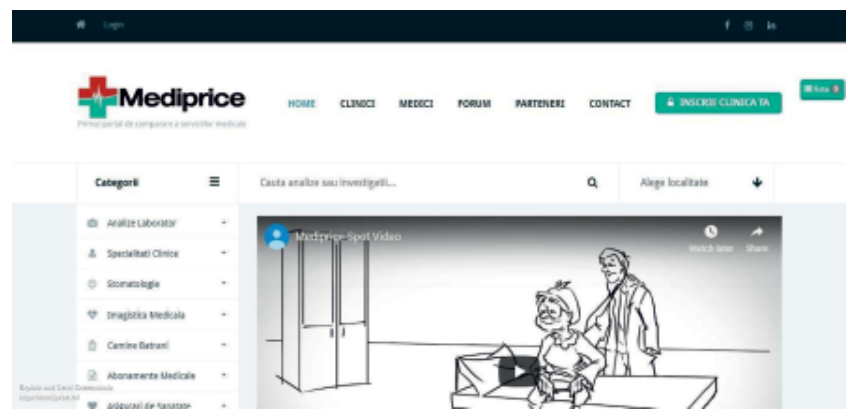

Figure 1. Mediprice medical platform ${ }^{5}$. 
to $30 \%$. At the information level, the first tool of Romanians remains www.google.ro. Mediprice platform currently collaborates with more than 80 private clinics both in the country and abroad, platform users having access to information on certain discounts of registered clinics, depending on their seasonality ${ }^{5}$.

Doctor's Advice is a centralizing platform of medical information in Romania. The Doctor's Advice (sfatulmedicului.ro) platform is the largest medical information hub in Romania, launched 15 years ago, being taken over by the private company Medlife. Established 15 years ago, sfatulmedicului.ro is among the top sites dedicated to the health segment in Romania (Figure 2). The platform has a monthly average of over 3.2 million unique users, or more than 12 million impressions. In addition to the information service, users access the medical self-assessment service and online interpretation of analyses on this platform (Figure 3$)^{6}$.

Doclandia is a subscription based platform for medical information. Doclandia.ro, the online platform through which Romanians have unlimited information from doctors, attracted 6,000 subscribers and 656 doctors specializing in internal medicine and family medicine. The platform is a complementary system for classical medicine through which users can get in tou-

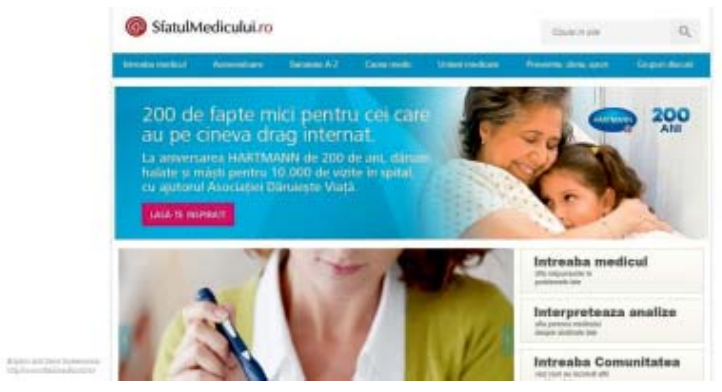

Figure 2. Doctor's Advice medical platform ${ }^{6}$.

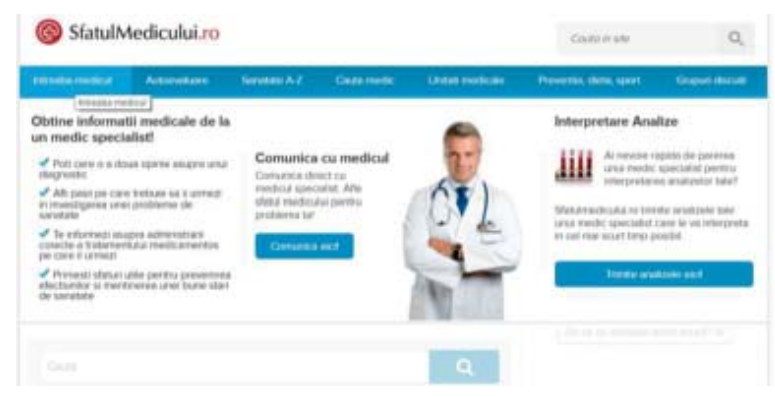

Figure 3. Doctor's Advice online support ${ }^{6}$.

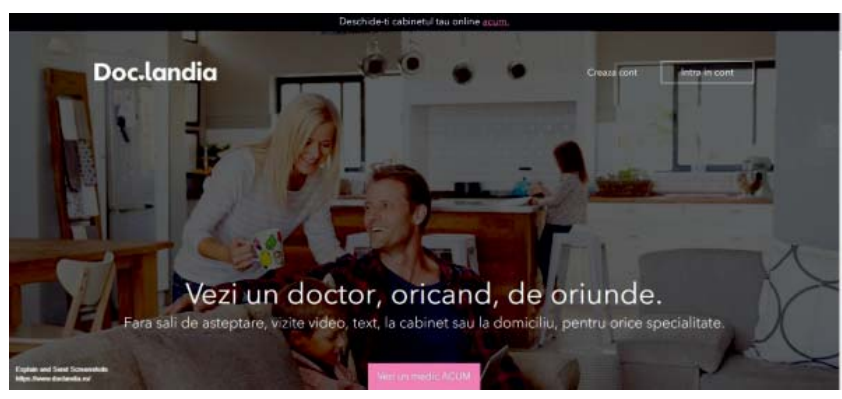

Figure 4. Doclandia medical platform?

ch with doctors for advice; the business model is based on monthly subscriptions (Figure 4$)^{7}$.

InfoMaterna.ro is an online platform dedicated to parenthood, especially mothers. This platform is the first Romanian portal dedicated to women, with $100 \%$ content provided by doctors. The project kicked off with the launch of the campaign celebrating 10,000 babies born in MedLife maternity units (Figure 5) ${ }^{8}$.

By the way the information is structured, this platform accompanies the woman from the moment she wants to get pregnant, is pregnant and is due to give birth, as well as during the recovery and care of the baby, all the information directly provided by specialists.

The site is structured in three categories: Women's Health, Maternity and Beauty, the content being made entirely by a team of doctors from MedLife. Women who want to have a baby can access information on ovulation monitoring, recommended pregnancy tests or types of birth (natural, caesarean or water birth), and those who have already given birth will receive advice on how to in which they can successfully breastfeed in the long term, healthy recipes for extra pounds or communication techniques for the best possible relationship with their child.

Planeta Roz is a platform specialised in providing information about breast cancer. Through this plat-

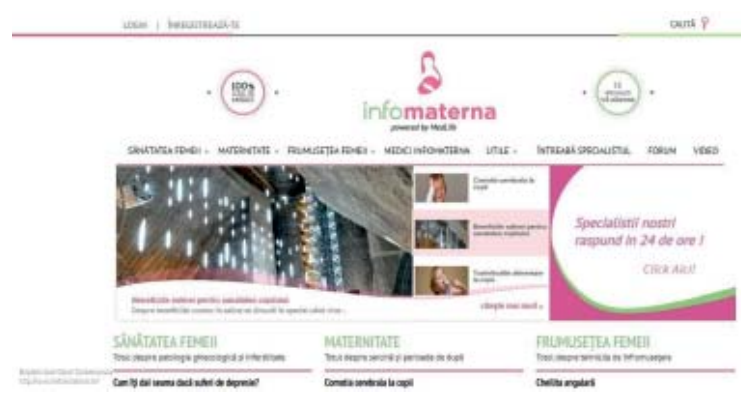

Figure 5. InfoMaterna Medical Platform ${ }^{8}$. 
form, Romanian women diagnosed with breast cancer receive free of charge, support, information, medical advice, psychological counselling and legal advice?.

PlanetaRoz.ro informs women about everything that means prevention, diagnosis, symptoms and treatment of breast cancer. Moreover, they can come into contact with the project's collaborating doctors, renowned specialists in the field of oncology and other complementary fields through interviews conducted in collaboration with them. Also, by accessing the chat module implemented on the platform, anyone can discuss in real time with the M.A.M.E. Association's advisors who will take their questions, send them to the doctors and get back with specialized responses (Figure 6).

PEDITEL 1791 is a pediatric call center. THE PEDITEL 1791 service is a service dedicated to parents who need professional medical advice for their children's health. Emergency pediatric medical advice by telephone works around the clock, being served by a pediatrician or doctor with emergency specialization. Call pediatric center PEDITEL 1791 is callable by the formation of the short number 1791, a number with standard tariff, without surcharge, to which responds a paediatrician or trained in emergency medicine. The service, initiated and implemented by the Romanian

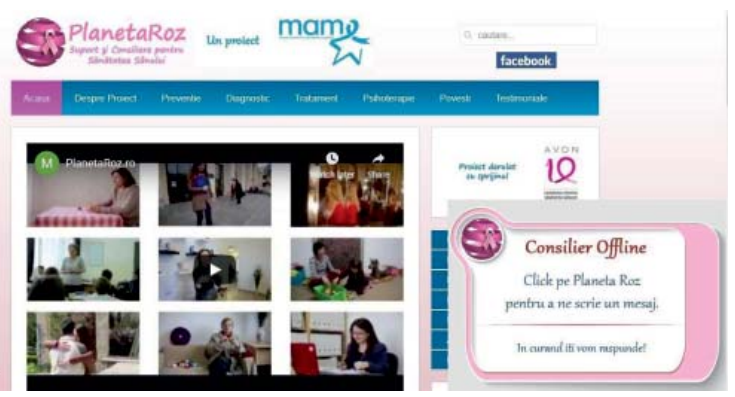

Figure 6. PlanetaRoz Medical Platform ${ }^{9}$.

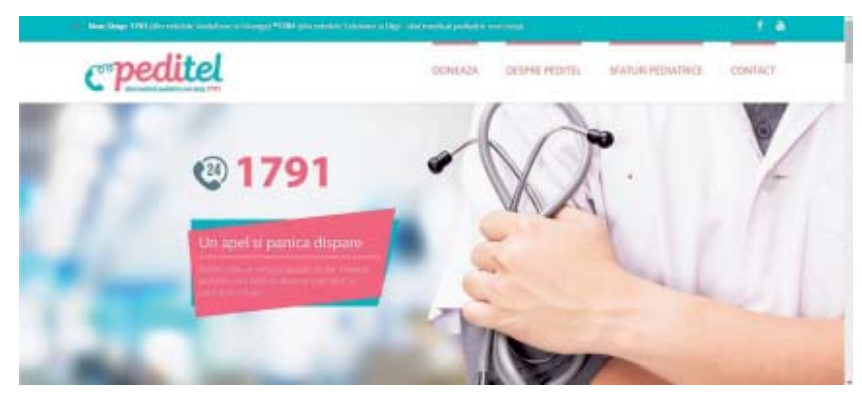

Figure 7. Peditel Medical platform ${ }^{10}$.
Parents Foundation, at Cluj Children's Hospital is a first in Romania ${ }^{10}$.

Asociația Limfom is a platform dedicated to patients with lymphomas. The main objectives of the platform and its application are to inform patients medically correct and to create the largest community of lymphoma patients in Romania. The online platform www.asociatialimfom.ro contains structured information, medically verified and several other main sections, including the Forum and the 'Ask the Doctor' section ${ }^{11}$. The forum was designed to unite patients, encourage them to share their experiences and to be able to interact easily, thus forming the largest community of patients with lymphoma in Romania. Regarding the section „Ask the doctor”, those diagnosed have access to advice received from haematology specialists. Moreover, on this platform there is also a database of doctors and hospitals in each county, so that all patients can quickly find the place where they can go to consult.

WebMedic is an interactive medical platform. Through the online platform WebMedic.ro, patients can receive medical responses from doctors and university professors, personalities of the medical world from the most important clinics and university centers in Romania ${ }^{12}$.

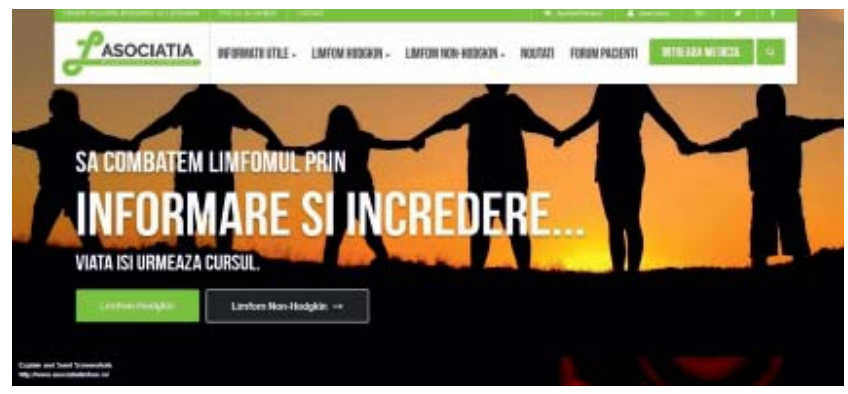

Figure 8. Asociația Limfom Medical platform ${ }^{11}$.

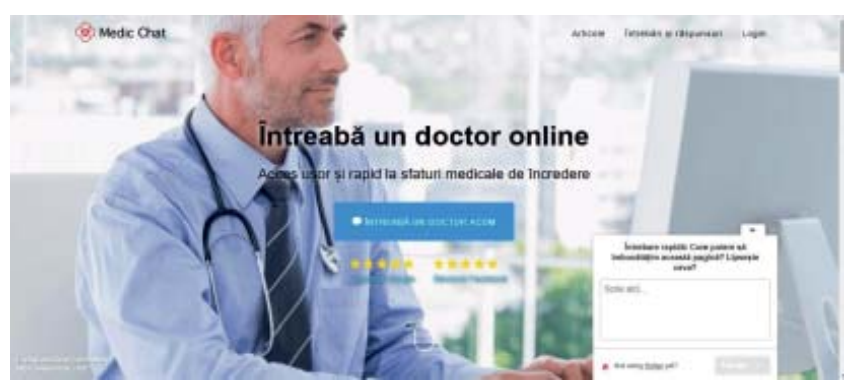

Figure 9. WebMedic Medical Platform² ${ }^{12}$ 
WebMedic.ro is a project initiated by ARCMed - Romanian Association for Medical Counseling, in partnership with ROmedic.ro. The project offers the facility to choose from a generous list of prestigious doctors, who provide online medical advice directly by email. The mechanism is simple: the user creates an account on the www.webmedic.ro, chooses from the list the doctor from whom he wants a response, fills in a medical file with information and details on the health problem, after which he sends the question. It may also upload, where appropriate, files with medical analyses, paraclinical examinations and images representative of his condition.

SpitalOnline.ro is a live doctor-patient chat platform. Romanian doctors launched the first online hospital in Europe, supported by specialists from the UK, the virtual health unit being the first live doctor-patient chat platform. Specifically, the project is a quick alternative to classic medical consultations through which patients will be able to benefit from medical services, 24 hours a day, offered in 30 specialties. A total of 150 doctors are involved in the project. SpitalOnline.ro aims to respond to this need of patients to be able to communicate at any time with their doctor, to ask questions and to receive answers even outside the classic consultation program ${ }^{13}$.

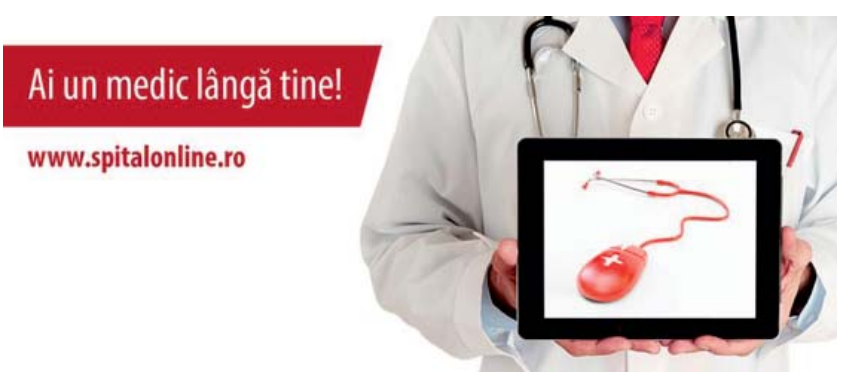

Figure 10. SpitalOnline Medical platform ${ }^{13}$.

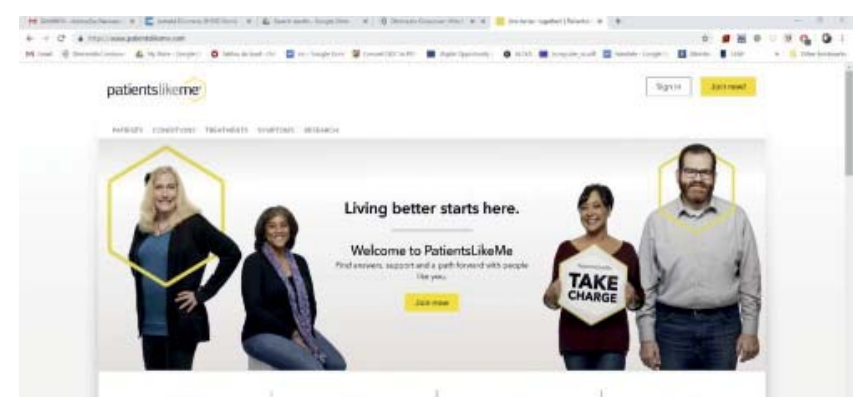

Figure 11. PatiencesLikeMe Platform ${ }^{14}$.

\section{INTERNATIONAL ONLINE MEDICAL PLATFORMS}

The PatientsLikeMe is a digital platform from USA, Boston that allows those suffering from conditions such as Parkinson's or depression to connect with others, share their experiences and better understand their treatment options and results ${ }^{14}$.

The MotherKnows is a digital platform from USA, which maintains children's records and health records, including immunizations, growth charts and operations, and is an advantage for any parent $\mathrm{t}^{15}$.

At Brigham Women Hospital from Boston, USA, the patients with specific chronic diseases requiring frequent visits are now able to have consultations with doctors online. After 600 virtual visits, BWH calculated that doctors had saved 200 hours. Furthermore, $94 \%$ of the patients surveyed were satisfied with the program and $74 \%$ felt that their relationship with their doctors had been improved ${ }^{16}$.

Medicitus.com, the information platform for French-speaking peoples where there is no subscription for patients, but they enjoy free access to the network of doctors registered with the National Council of the Order of Physicians ${ }^{17}$.

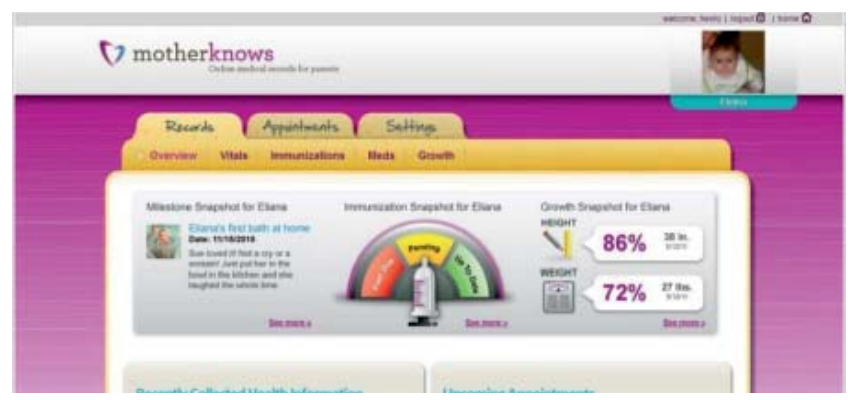

Figure 12. MotherKnows platform ${ }^{15}$.

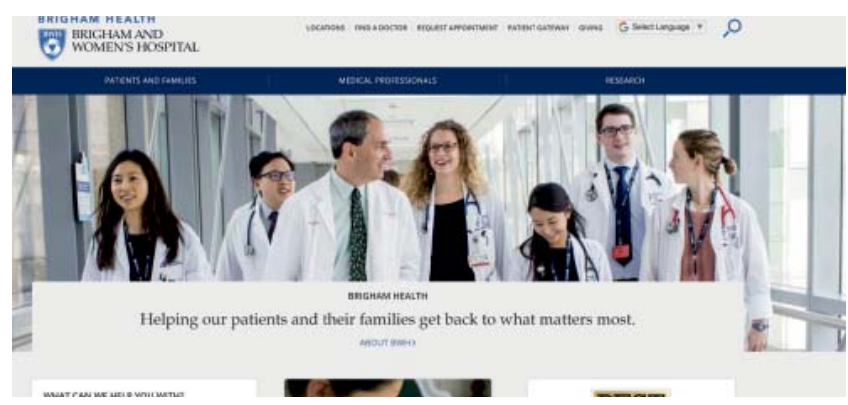

Figure 13. Brigham Women Hospital ${ }^{16}$. 


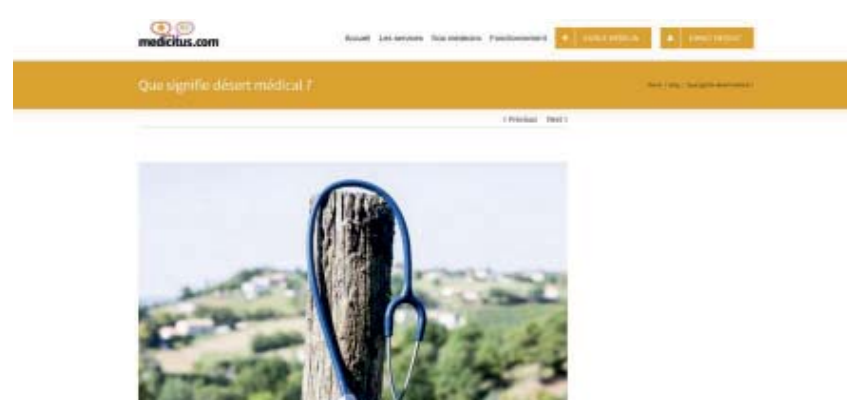

Figure 14. Medicitus platform ${ }^{17}$.

The platform Neurinfo.org refers to human and neuro-informatics imaging in vivo, especially in the case of diseases of the nervous system. It is open to a broad community of medical and scientific users at regional, national and international level ${ }^{18}$.

\section{CONCLUSIONS}

European countries have made a significant impact on health services to the population, but there are still large inequalities, both between countries and within each system. Life expectancy at birth in the Member States of the European Union (EU) has increased by more than five years, on average, since 1990, although the gap between the countries with the highest and lowest life expectancy remains around eight years. There are also persistent inequalities within countries, between people from different socio-economic groups, with people with higher levels of education and income who enjoy better health and who live longer years than the most Disadvantaged. These disparities are linked to several factors, including some outside the health care system, such as the environment in which people live, lifestyle and individual behaviours, as well as differences in access to and quality of care.

There are currently 56,295 health facilities in Romania, from hospitals, offices and specialist clinics, to pharmacies and analysis laboratories, and of these, 75\% are private, according to a study based on data from the National Institute of Statistics (INS) and presented by the Romanian Health Alliance and the Patronage of Private Medical Service Providers. According to the National Statistical Institute, the development of the private medical system has expanded 60 times since 1997 in terms of medical units and staff employed. So it is that, by 2014 , the number of beds in private medical facilities had increased from 63 to almost 5800. At the same

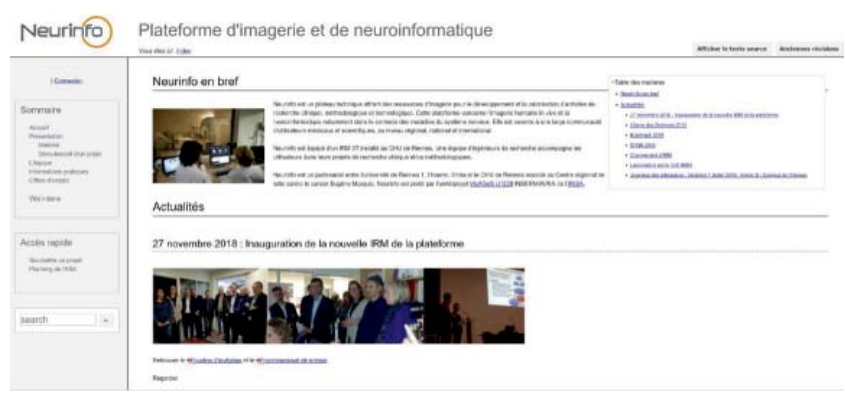

Figure 15. Neurolnfo platform ${ }^{18}$.

time, public-system beds have dwindled from 166,411 to 125,192 , which is a decrease of $24.76 \%$. The largest decreases are recorded in Arad and Tulcea counties, where the number of beds has halved. Most beds in the private system are in Bucharest (1312), Iasi (709), Brasov (466) and Arad (345), and at the opposite pole, there are 14 counties without such a facility," the press release reads.

The problem is felt more intensely in rural areas (15.8\% of people aged 15 and over were unable to consult a specialist doctor, compared to $12.5 \%$ of urban people). Of the social categories that would have needed a specialist consultation but could not perform it, pensioners are distinguished by the highest frequency, $30.1 \%$ of whom face the impossibility of participating in a medical consultation, despite imminent health problems that occur with advancing age. They are followed by the unemployed and farmers (over 12\%).

More than three quarters of those who were unable to consult a specialist doctor stated as the main reason the material situation which did not allow them to carry out the consultation. The second reason for not making a visit to a specialist doctor is that people have neglected the health problem that would have required the consultation, waiting for the problem to be resolved on its own (6.3\% of the people who would have required a consultation). The third reason in order of frequency of occurrence is the distance too large or the lack of means of transport, declared with a higher frequency by people from rural areas $(7.3 \%$ compared to $0.8 \%$ in urban areas).

In conclusion, the digitalisation should be a constant process in healthcare. This should provide tolls and instruments that helps the medical personnel and patients, and will engage the stakeholders in an information ecosystem, that should provide better healthcare services for persons, families, communities and populations in general. 
Compliance with ethics requirements: The authors declare no conflict of interest regarding this article. The authors declare that all the procedures and experiments of this study respect the ethical standards in the Helsinki Declaration of 1975, as revised in 2008(5), as well as the national law.

\section{References}

1. Schwab Klaus, The Fourth Industrial Revolution, Penguin Books Ltd., 2017:1-2

2. Digital Futures Final Report "A Journey into 2050 Visions and Policy Challenges", DG CONNECT - European Commission, 2016

3. McKinsey \& Company, McKinsey on Healthcare: Best of 2019, January 2020

4. http://saninfo.csdj.ro/

5. Mediprice platform, http://medprice.ro/

6. Sfatul Medicului platform, http://www.sfatulmedicului.ro/

7. Doclandia platform, https://www.doclandia.ro/

8. Infomaterna platform, http://www.infomaterna.ro/

9. Planeta roz platform, http://planetaroz.ro/

\section{Acknowledgement}

This work was supported by a grant of the Romanian National Authority for Scientific Research and Innovation, CNCS/CCCDI - UEFISCDI, project number PN-III-P2-2.1-CLS-2017-0045, within PNCDI III. Project name: Developing an Innovative Health Information System - SANINFO, with applications in the Romanian language for the Innovative Cluster for Health „Dunarea de Jos”.

10. PEDITEL service, https://www.peditel.ro/

11. Limfom Association platform, http://www.asociatialimfom.ro/

12. WebMedic platform, https://webmedic.ro/

13. SpitalOnline platform, SpitalOnline.ro

14. PatientsLikeMe digital platform, https://www.patientslikeme $\mathrm{com} /$

15. MotherKnows platform, https://techcrunch.com/tag/mother knows/

16. Brigham Women Hospital community, https://www.brighamandwomens.org/

17. Medicitus platform, http://www.medicitus.com/

18. Neurinfo platform, http://www.neurinfo.org/ 
